\title{
HES5 wt Allele
}

National Cancer Institute

\section{Source}

National Cancer Institute. HES5 wt Allele. NCI Thesaurus. Code C84296.

Human HES5 wild-type allele is located in the vicinity of $1 \mathrm{p} 36.32$ and is approximately $2 \mathrm{~kb}$ in length. This allele, which encodes transcription factor HES-5 protein, may be involved in the modulation of transcription. 